\title{
MENINGKATKAN MINAT BELAJAR MATEMATIKA MELALUI MODEL PEMBELAJARAN KOOPERATIF TIPE STAD DAN PEMBELAJARAN EKSPOSITORI
}

\author{
Ika Sriyanti \\ STKIP Subang \\ ikasriyanti99@gmail.com
}

\begin{abstract}
ABSTRAK
Tujuan dari penelitian ini adalah untuk mengetahui bagaimana minat siswa yang menggunakan pembelajaran kooperatif tipe STAD dan Pembelajaran Ekspositori. Minat belajar siswa adalah penerimaan akan suatu hubungan antara diri sendiri dengan sesuatu di luar sendiri. Semakin kuat hubungan tersebut semakin besar minat siswa untuk belajar matematika. Populasi yang diambil di SMPN 1 Pamanukan dengan sampel siswa kelas 8A untuk kelas eksperimen yang menggunakan model pembelajaran kooperatif tipe STAD dan siswa kelas 8C untuk kelas kontrol dengan menggunakan pembelajaran Ekspositori. Metode yang digunakan dengan pendekatan kualitatif. Instrumen dalam penelitian ini yaitu jenis non tes, berupa angket dan wawancara. Berdasarkan analisis MSI bahwa rata-rata siswa yang mendapatkan pembelajaran kooperatif tipe STAD rataratanya 91,065 lebih besar dari rata-rata siswa yang menggunakan pembelajaran Ekspositori dengan rata-rata 85,478. Angket disusun dengan menggunakan skala Likert, dengan tujuan untuk mengetahui setiap indikator dari minat siswa dengan menggunakan pembelajaran kooperatif tipe STAD dan pembelajaran Ekspositori. Sehingga dapat disimpulkan bahwa minat pembelajaran kooperatif tipe STAD lebih baik dari pada minat siswa dalam pembelajaran Ekspositori dan minat siswa dalam pembelajaran kooperatif tipe STAD bersifat positif.
\end{abstract}

Kata kunci : Minat Siswa, Kooperatif tipe STAD, Ekspositori.

\begin{abstract}
The purpose of this research is to find out how the interests of students who use STAD type cooperative learning and expository learning. Student learning interest is the acceptance of a relationship between oneself and something outside of oneself. The stronger the relationship the greater the interest of students to learn mathematics. The population taken at SMAN 1 Pamanukan with a sample of $8 \mathrm{~A}$ class students for the experimental class using the STAD type cooperative learning model and $8 \mathrm{C}$ grade students for the control class using Expository learning. The method used with a qualitative approach is descriptive. The instruments in this study are non-test types, in the form of questionnaires and interviews. Based on the MSI analysis that the average student who gets STAD type cooperative learning is on average 91,065 greater than the average student who uses Expository learning with an average of 85,478 . The questionnaire was prepared using a likert scale, with the aim to find out each indicator of student interest by using STAD type cooperative learning and expository learning. So it can be concluded that the interest in STAD type cooperative learning is better than student interest in Expository learning and student interest in STAD type cooperative learning is positive
\end{abstract}

Keywords: student interest, cooperative type STAD, expository

\section{PENDAHULUAN}

Minat belajar merupakan salah satu modal awal dalam pembelajaran siswa, baik ketika berada di rumah maupun di sekolah. Untuk mewujudkan cita-citanya siswa harus memiliki minat belajar yang tinggi. Oleh karena itu guru lebih bekerja keras agar siswa 
memiliki minat belajar yang tinggi. Bertahun-tahun hasil pembelajaran matematika di sekolah selalu dikeluhkan. Berdasarkan hal ini guru menyadari bahwa matematika sering dipandang sebagai mata pelajaran yang sulit sehingga banyak siswa yang kurang berminat dan dihindari oleh sebagian besar siswa.

Dari hasil observasi dari guru mata pelajaran matematika SMPN 1 Pamanukan mengatakan bahwa minat belajar siswa masih rendah, hal ini ditunjukan dari permasalahan berikut, yaitu: 1) Apabila guru sedang menjelaskan materi masih banyak siswa yang mainmain dengan teman sebangkunya.2) Apabila guru bertanya kepada siswa tentang materi yang baru saja diajarkan, kebanyakan siswa diam saja dan tidak merespon pertanyaan dari guru.3) Sebagian besar siswa tidak berani bertanya kepada guru jika mereka belum memahami materi yang diajarkan. 4) Masih ada siswa yang kaget jika guru meminta untuk mengerjakan soal di papan tulis. 5) Kadang masih ada siswa yang tidak mengerjakan tugas rumah karena alasan tidak mengerti. Dengan kurangnya minat belajar akan berakibat pada hasil belajar yang kurang maksimal. Hasil wawancara dengan guru kelas VIII dan siswa kelas VIII SMP Negeri 1 Pamanukan setiap tahunnya, menunjukkan bahwa sebagian besar siswa menganggap matematika merupakan mata pelajaran yang sulit dipahami sehingga banyak siswa yang tidak menyenangi. Yang terjadi di SMP Negeri 1 Pamanukan khususnya kelas VIII minat untuk belajar matematika masih kurang, sehingga hasil belajarnya juga kurang.

Hasil observasi saat proses pembelajaran memperlihatkan bahwa guru belum sepenuhnya melibatkan siswa dalam proses pembelajaran. Guru kebanyakan mengajar dengan menggunakan metode pembelajaran ekspositori yaitu guru hanya mengajar, menjelaskan, memberi contoh, memberi PR dan ulangan harian walaupun sudah menggunakan kurikulum kurtilas. Bahkan jarang sekali guru mengajak diskusi tentang materi yang disampaikan. Menurut Ruseffendi (2006:290) pembelajaran ekspositori adalah model pembelajaran yang berupa ceramah, keterampilannya mengenai pola matematika kemudian siswa bertanya, guru memeriksa atau mengecek apakah siswa sudah mengerti apa belum. Guru harus tepat dalam memilih metode dan strategi pembelajaran, guru yang kurang menguasai materi tentu akan kesulitan di dalam mengajar. Hal ini dapat mengakibatkan siswa kurang mengerti tentang materi yang disampaikan sehingga siswa menjadi malas untuk belajar dan menganggap materi tersebut sulit.

Oleh karena itu salah satu model pembelajaran yang melibatkan siswa secara aktif adalah pembelajaran kooperatif. Anita Lie mengungkapkan bahwa pembelajaran kooperatif merupakan sistem pembelajaran yang memberi kesempatan kepada peserta 
didik untuk kerja sama dengan siswa lain dalam tugas yang terstruktur. Salah satunya model pembelajaran kooperatif tipe STAD (Student Team Achievement Divisions). Pembelajaran kooperatif tipe STAD yang dikembangkan oleh Robert Slavin dan temantemannya di Universitas John Hopkin (dalam Slavin, 1995) merupakan pembelajaran kooperatif yang paling sederhana, dan merupakan pembelajaran kooperatif yang cocok digunakan oleh guru yang baru mulai menggunakan pembelajaran kooperatif.

Model pembelajaran kooperatif tipe STAD merupakan tim belajar beranggotakan empat orang yang merupakan campuran menurut tingkat kinerjanya, jenis kelamin dan suku. Guru menyajikan pelajaran kemudian siswa bekerja dalam tim untuk memastikan bahwa seluruh anggota tim telah menguasai pelajaran tersebut. kemudian seluruh siswa melakukan kuis tentang materi itu dengan catatan, saat kuis mereka tidak boleh saling membantu. Model Pembelajaran Kooperatif tipe STAD merupakan pendekatan Cooperative Learning yang menekankan pada aktivitas dan interaksi di antara siswa untuk saling memotivasi dan saling membantu dalam menguasai materi pelajaran guna mencapai prestasi yang maksimal. Guru yang menggunakan STAD mengajukan informasi akademik baru kepada siswa setiap minggu menggunakan presentasi Verbal atau teks sehingga dapat memberikan perhatian terhadap siswa. Hubungan yang lebih akrab akan terjadi antara guru dengan siswa maupun antara siswa dengan siswa.

Pada dasarnya minat adalah penerimaan akan suatu hubungan antara diri sendiri dengan sesuatu diluar sendiri (Slameto, 2003: 180). Semakin kuat atau dekat hubungan tersebut, semakin besar minat untuk belajar matematika. Disini peran guru sangat berpengaruh, seorang guru harus bisa membangkitkan minat belajar siswa untuk belajar matematika dengan metode yang digunakan bahkan materi pelajaran yang lebih mudah dipelajari. Dengan siswa memiliki minat untuk belajar matematika yang tinggi dapat meningkatkan ketekunan belajar siswa bahkan meningkatkan hasil belajar siswa. Dengan minat yang tinggi maka siswa pun akan berusaha mempelajari dan memahami materi dengan tujuan untuk mendapatkan hasil ulangan yang meningkat. Pembelajaran kooperatif tipe STAD dapat menarik perhatian siswa sehingga dapat menumbuhkan minat mereka terhadap pembelajaran matematika,sehingga siswa dapat dengan mudah memahami matematika. Berdasarkan pembelajaran kooperatif tipe STAD yang dimiliki siswa memungkinkan tumbuhnya minat menjadikan pembelajaran matematika menjadi menarik sehingga diharapkan dapat meningkatkan minat belajar siswa akan matematika. 


\section{METODE}

Penelitian ini menggunakan pendekatan kualitatif dalam bentuk angket dan wawancara. Angket digunakan untuk mengungkap tentang minat siswa. Angket ini diberikan kepada siswa kelompok eksperimen dan kontrol dilaksanakan sesudah pelaksanaan kegiatan pembelajaran dengan menggunakan model kooperatif tipe STAD pada kelas eksperimen dan menggunakan pembelajaran ekspositori pada kelas kontrol. Instrumen ini diberikan kepada siswa setelah pelaksanaan proses pembelajaran. Instrumen angket skala minat siswa yang digunakan adalah skala Likert. Skala minat ini berupa pertanyaan atau pernyataan yang sudah dilengkapi jawabannya. Siswa diminta untuk membaca setiap pertanyaan atau pernyataan tersebut. Skala Likert ini terbagi dalam lima kategori yang tersusun secara bertingkat mulai dari SS ( Sangat Setuju), S (setuju), N (Netral), TS (Tidak Setuju), dan STS (Sangat Tidak Setuju).

Tabel 1. Indikator Minat Siswa

\begin{tabular}{cl}
\hline Aspek Minat & \multicolumn{1}{c}{ Indikator } \\
\hline Perasaan & a. Perasaan siswa saat mengikuti pembelajaran kooperatif tipe STAD \\
Senang & b. Perasaan siswa saat belajar matematika secara berkelompok \\
& c. Perasaan Siswa saat mengerjakan soal pemahaman matematika
\end{tabular}

Perhatian a. Perhatian siswa saat mengikuti pembelajaran kooperatif tipe STAD

b. Perhatian siswa saat diskusi pelajaran Matematika

Konsentrasi a. Konsentrasi siswa saat mengikuti pelajaran matematika di sekolah

b. Konsentrasi siswa saat mengikuti pelajaran matematika dirumah

Kesadaran a. Kesadaran tentang belajar dirumah

b. Kesadaran siswa untuk bertanya

c. Kesadaran untuk mengikuti les pelajaran matematika

Sumber: Slameto (2003)

Untuk menganalisis hasil angket ini, maka skala kualitatif dari minat siswa diubah ke skala kuantitatif berupa bilangan (Skor). Untuk pertanyaan atau pernyataan yang bersifat positif, SS diberi skor tertinggi hingga menuju STS maka skor diberikan berangsur-angsur menurun. Sedangkan untuk pertanyaan dan pernyataan negatif SS diberi skor terendah hingga menuju STS diberi skor berangsur-angsur makin tinggi. Penskoran untuk pernyataan positif adalah sebagai berikut (SS) diberi skor 5, (S) skornya 4, (N) skornya 3, (TS) skornya 2 dan (STS) skornya 1. Sedangkan untuk pernyataan negatif penskorannya adalah sebagai berikut: (SS) diberi skor 1, (S) skornya 2, (N) skornya 3, (TS) skornya 4 
dan (STS) skornya 5. Instrumen angket minat siswa terlebih dahulu diuji cobakan dan akan dianalisis atau akan ditentukan koefisien validitas dan reliabilitasnya, koefisien korelasi validitasnya menggunakan excel dan program SPSS dengan model product moment pearson sedangkan koefisien korelasi reliabilitasnya menggunakan Cronbach's Alpha.

Analisis data kualitatif, yaitu data hasil angket minat siswa diubah ke dalam data kuantitatif, kemudian hasilnya dianalisis secara statistik dan deskriptif. Angket berupa data ordinal kemudian diubah menjadi skala interval dengan menggunakan MSI (Method of Successive interval). Menurut Slameto (2003) Indikator minat bisa dilihat di tabel 1.

\section{HASIL DAN PEMBAHASAN}

Untuk melihat minat siswa terhadap pembelajaran matematika, siswa diberikan angket minat. Angket tersebut berisikan pernyataan yang berkaitan dengan minat siswa yang menyangkut dengan perasaan siswa, perhatian siswa, konsentrasi siswa, dan kesadaran siswa. Angket diberikan sesudah pembelajaran kooperatif tipe STAD dan juga angket diberikan pada siswa yang menggunakan pembelajaran ekspositori. Pertama Proses pengolahan angket menggunakan MSI untuk mengetahui rata-rata siswa yang menggunakan pembelajaran kooperatif tipe STAD dan pembelajaran ekspositori.Tujuan menggunakan MSI (Method of Successive Interval) untuk merubah data ordinal ke interval.

Tabel 2. Analisis MSI Interval Angket Minat

\begin{tabular}{lc}
\hline Model Pembelajaran & Rata-rata \\
\hline Kooperatif tipe STAD & 91,065 \\
Ekspositori & 85,478 \\
\hline
\end{tabular}

Berdasarkan analisis MSI bahwa rata-rata siswa yang mendapatkan pembelajaran kooperatif tipe STAD rata ratanya 91,065 lebih besar dari rata-rata siswa yang menggunakan pembelajaran Ekspositori dengan rata-rata 85,478. Angket disusun dengan menggunakan skala Likert, dengan tujuan untuk mengetahui setiap indikator dari minat siswa yang menggunakan pembelajaran kooperatif tipe STAD. Setelah data diolah maka diperoleh hasil sebagai berikut: 


\section{Pengolahan Angket Minat Siswa yang menggunakan pembelajaran kooperatif tipe STAD \\ a) Perasaan Senang terhadap pembelajaran kooperatif STAD}

Tabel 3. Hasil Minat siswa terhadap perasaan siswa

\begin{tabular}{lcrrrrrrrl}
\hline \multirow{2}{*}{\multicolumn{1}{c}{ Indikator }} & No & \multicolumn{4}{c}{ Jawaban } & \multirow{2}{*}{$\begin{array}{c}\text { Skor } \\
\text { rata-rata }\end{array}$} & \multirow{2}{*}{ Kriteria } \\
\cline { 3 - 7 } & Soal & SS & S & N & TS & TST & \\
\hline Perasaan siswa saat & 1 & 26 & 4 & 0 & 0 & 0 & 4,86 & Sangat baik \\
mengikuti pembelajaran & 2 & 0 & 1 & 5 & 13 & 11 & 4,13 & Baik \\
kooperatif STAD & 3 & 11 & 18 & 0 & 0 & 1 & 4,26 & Baik \\
\hline Perasaan siswa saat belajar & 4 & 0 & 1 & 2 & 8 & 19 & 4,50 & Baik \\
matematika secara kelompok & 5 & 14 & 11 & 3 & 0 & 2 & 4,16 & Baik \\
& 6 & 0 & 2 & 6 & 12 & 10 & 4,00 & Baik \\
\hline Perasaan siswa saat & 7 & 15 & 15 & 0 & 0 & 0 & 4,50 & Baik \\
mengerjakan soal & 8 & 1 & 0 & 1 & 15 & 13 & 4,30 & Baik \\
pemahaman matematika & 9 & 12 & 14 & 2 & 1 & 1 & 4,16 & Baik \\
\hline Rata-rata & & & & & & & $\mathbf{4 , 3 2}$ & Baik \\
\hline
\end{tabular}

Berdasarkan jawaban siswa, dapat diketahui bahwa secara keseluruhan siswa memperhatikan kriteria baik terhadap pembelajaran kooperatif tipe STAD dengan rerata 4,32 sehingga dapat disimpulkan bahwa minat siswa memperlihatkan minat yang baik terhadap pembelajaran kooperatif tipe STAD.

b) Perhatian siswa terhadap pembelajaran kooperatif tipe STAD

Tabel 4. Hasil Minat siswa terhadap perhatian siswa

\begin{tabular}{lrrrrrrrr}
\hline \multirow{2}{*}{\multicolumn{1}{c}{ Indikator }} & No & \multicolumn{4}{c}{ Jawaban } & Skor & \multirow{2}{*}{ rata-rata } & Kriteria \\
\cline { 3 - 7 } & Soal & SS & S & N & TS & TST & \\
\hline Perhatian siswa saat mengikuti & 10 & 1 & 1 & 6 & 17 & 5 & 3,80 & Baik \\
pelajaran kooperatif tipe STAD & 11 & 14 & 15 & 1 & 0 & 0 & 4,43 & Baik \\
& 12 & 1 & 5 & 11 & 9 & 4 & 4,33 & Baik \\
\hline Perhatian siswa saat diskusi & 13 & 11 & 15 & 1 & 1 & 2 & 4,06 & Baik \\
pelajaran matematika & 14 & 2 & 1 & 1 & 14 & 12 & 4,10 & Baik \\
& 15 & 17 & 13 & 0 & 0 & 0 & 4,56 & Baik \\
\hline Rata-rata & & & & & & & $\mathbf{4 , 2 1}$ & Baik \\
\hline
\end{tabular}

Pada tabel 4. skor rata-rata dari semua pernyataan yang berhubungan dengan minat siswa terhadap pembelajaran kooperatif tipe STAD mempunyai kriteria baik dengan skor rata-rata 4,21 hal ini dapat disimpulkan bahwa siswa mempunyai perhatian yang baik dalam pembelajaran kooperatif tipe STAD. 
c) Konsentrasi siswa terhadap Kemampuan pemahaman Matematika

Tabel 5. Hasil minat siswa terhadap Konsentrasi Siswa

\begin{tabular}{lrrrrrrrr}
\hline \multicolumn{1}{c}{ Indikator } & No & \multicolumn{4}{c}{ Jawaban } & \multicolumn{2}{c}{ Skor } & Kriteria \\
\cline { 3 - 7 } & Soal & SS & S & N & TS & TST & rata-rata & \\
\hline Konsentrasi siswa di saat mengikuti & 16 & 1 & 0 & 3 & 14 & 12 & 4,10 & Baik \\
pelajaran pemahaman matematika & 17 & 13 & 13 & 1 & 1 & 2 & 4,13 & Baik \\
& 18 & 0 & 1 & 4 & 12 & 13 & 4,23 & Baik \\
\hline Konsentrasi siswa saat mengerjakan & 19 & 15 & 11 & 3 & 0 & 1 & 4,30 & Baik \\
soal pemahaman matematika & 20 & 1 & 0 & 3 & 8 & 18 & 4,40 & Baik \\
& 21 & 9 & 14 & 5 & 1 & 1 & 3,96 & Baik \\
\hline Rata-rata & & & & & & $\mathbf{4 , 1 8}$ & Baik \\
\hline
\end{tabular}

Skor rata-rata yang tertera pada tabel 5 termasuk kriteria baik dengan skor rata-rata 4,18 , hal ini dapat disimpulkan bahwa soal soal kemampuan pemahaman matematika yang diberikan siswa dapat konsentrasi dan menarik untuk diselesaikan.

\section{d) Kesadaran siswa terhadap Pembelajaran Matematika}

Tabel 6. Hasil minat siswa terhadap Kesadaran siswa

\begin{tabular}{lrrrrrrrl}
\hline \multicolumn{1}{c}{ Indikator } & No & \multicolumn{4}{c}{ Jawaban } & & Skor & Kriteria \\
& Soal & SS & S & N & TS & TST & rata-rata & \\
\hline Kesadaran tentang belajar & 22 & 2 & 0 & 4 & 15 & 9 & 3,96 & Baik \\
matematika & 23 & 12 & 11 & 2 & 2 & 3 & 3,90 & Baik \\
& 24 & 3 & 2 & 3 & 13 & 9 & 3,76 & Baik \\
\hline Kesadaran siswa untuk bertanya & 25 & 14 & 15 & 1 & 0 & 0 & 4,43 & Baik \\
& 26 & 1 & 2 & 7 & 11 & 9 & 3,83 & Baik \\
& 27 & 19 & 9 & 1 & 1 & 0 & 4,53 & Baik \\
\hline Kesadaran untuk mengikuti les & 29 & 18 & 11 & 1 & 0 & 0 & 4,56 & Baik \\
pelajaran matematika & 30 & 0 & 0 & 5 & 5 & 20 & 3,83 & Baik \\
\hline Rata-rata & & & & & & $\mathbf{4 , 0 5}$ & Baik \\
\hline
\end{tabular}

Berdasarkan tabel 6 jawaban siswa dapat diketahui bahwa secara keseluruhan siswa memperlihatkan kriteria baik terhadap pembelajaran matematika, dengan rerata 4,05 sehingga dapat disimpulkan bahwa siswa mempunyai kesadaran yang baik dalam pembelajaran matematika. 
2. Pengolahan Angket Minat Siswa yang menggunakan pembelajaran Ekspositori

a) Perasaan Senang terhadap pembelajaran Ekspositori

Tabel 7. Hasil Minat siswa terhadap perasaan siswa

\begin{tabular}{lrrrrrrrrl}
\hline \multicolumn{1}{c}{ Indikator } & No & \multicolumn{4}{c}{ Jawaban } & & Skor rata- & Kriteria \\
\cline { 3 - 6 } & Soal & SS & S & N & TS & TST & rata & \\
\hline Perasaan siswa saat mengikuti & 1 & 0 & 13 & 8 & 9 & 0 & 3,13 & Cukup \\
pembelajaran ekspositori & 2 & 0 & 5 & 15 & 10 & 0 & 3,16 & Cukup \\
& 3 & 0 & 20 & 10 & 0 & 0 & 3,66 & Baik \\
\hline Perasaan siswa saat belajar & 4 & 0 & 1 & 4 & 23 & 2 & 3,86 & Baik \\
matematika & 5 & 3 & 19 & 4 & 4 & 0 & 3,70 & Baik \\
& 6 & 0 & 2 & 5 & 22 & 1 & 3,73 & Baik \\
\hline Perasaan siswa saat & 7 & 0 & 26 & 4 & 0 & 0 & 3,86 & Baik \\
mengerjakan soal & 8 & 1 & 8 & 1 & 20 & 0 & 3,33 & Cukup \\
& 9 & 0 & 16 & 13 & 1 & 0 & 3,50 & Cukup \\
\hline Rata-rata & \multicolumn{1}{c}{} & & & & $\mathbf{3 , 5 5}$ & Cukup \\
\hline
\end{tabular}

Menurut tabel 7 berdasarkan jawaban siswa, dapat diketahui bahwa secara keseluruhan siswa memperhatikan kriteria cukup terhadap pembelajaran ekspositori dengan rerata 3,55 sehingga dapat disimpulkan bahwa minat siswa memperlihatkan minat yang cukup terhadap pembelajaran ekspositori

\section{b) Perhatian siswa terhadap pembelajaran kooperatif tipe STAD}

Tabel 8. Hasil Minat siswa terhadap perhatian siswa

\begin{tabular}{lrrrrrrrrl}
\hline \multicolumn{1}{c}{ Indikator } & No & \multicolumn{4}{c}{ Jawaban } & & Skor rata- & Kriteria \\
& Soal & SS & S & N & TS & TST & rata & \\
\hline Perhatian siswa saat mengikuti & 10 & 1 & 1 & 10 & 18 & 0 & 3,50 & Cukup \\
pelajaran ekspositori & 11 & 0 & 15 & 5 & 9 & 1 & 3,13 & Cukup \\
& 12 & 1 & 3 & 19 & 6 & 1 & 4,10 & Baik \\
\hline Perhatian siswa saat pelajaran & 13 & 0 & 26 & 1 & 2 & 1 & 3,86 & Baik \\
matematika & 14 & 0 & 0 & 3 & 27 & 0 & 3,90 & Baik \\
& 15 & 0 & 7 & 14 & 9 & 0 & 2,93 & Cukup \\
\hline Rata-rata & & & & & & & $\mathbf{3 , 5 7}$ & Cukup \\
\hline
\end{tabular}

Pada tabel 8 skor rata-rata dari semua pernyataan yang berhubungan dengan minat siswa terhadap pembelajaran ekspositori mempunyai kriteria cukup dengan skor rata-rata 3,57 hal ini dapat disimpulkan bahwa siswa menunjukan mempunyai perhatian yang cukup dalam pembelajaran ekspositori 
c) Konsentrasi siswa terhadap Kemampuan pemahaman Matematika

Tabel 9. Hasil minat siswa terhadap Konsentrasi Siswa

\begin{tabular}{lrrrrrrrrl}
\hline \multicolumn{1}{c}{ Indikator } & No & \multicolumn{4}{c}{ Jawaban } & & Skor & Kriteria \\
& Soal & SS & S & N & TS & TST & rata-rata & \\
\hline Konsentrasi siswa di saat mengikuti & 16 & 2 & 1 & 2 & 24 & 1 & 3,70 & Baik \\
pelajaran pemahaman matematika & 17 & 0 & 11 & 9 & 10 & 0 & 3,03 & Cukup \\
& 18 & 0 & 10 & 2 & 18 & 0 & 3,26 & Cukup \\
\hline Konsentrasi siswa saat mengerjakan & 19 & 0 & 12 & 2 & 15 & 1 & 2,83 & Cukup \\
soal & 20 & 0 & 19 & 4 & 7 & 0 & 2,60 & Cukup \\
& 21 & 0 & 14 & 2 & 13 & 1 & 2,96 & Cukup \\
\hline Rata-rata & & & & & & & $\mathbf{3 , 0 6}$ & Cukup \\
\hline
\end{tabular}

Skor rata-rata yang tertera pada tabel 9 termasuk kriteria cukup dengan skor rata-rata 3,06, hal ini dapat disimpulkan bahwa soal matematika yang diberikan siswa cukup konsentrasi dan menarik untuk diselesaikan.

\section{d) Kesadaran siswa terhadap Pembelajaran Matematika}

Tabel 10. Hasil minat siswa terhadap Kesadaran siswa

\begin{tabular}{lrrrrrrrl}
\hline \multirow{1}{*}{ Indikator } & No & \multicolumn{4}{c}{ Jawaban } & & Skor & \multirow{2}{*}{ Kriteria } \\
\cline { 3 - 7 } & Soal & SS & S & N & TS & TST & rata-rata & \\
\hline Kesadaran tentang belajar & 22 & 1 & 1 & 3 & 25 & 0 & 3,73 & Baik \\
matematika & 23 & 0 & 20 & 7 & 2 & 1 & 3,66 & Baik \\
& 24 & 0 & 4 & 5 & 21 & 9 & 5,06 & Sangat baik \\
\hline Kesadaran siswa untuk bertanya & 25 & 0 & 12 & 2 & 15 & 1 & 2,83 & cukup \\
& 26 & 2 & 4 & 10 & 14 & 0 & 2,83 & cukup \\
& 27 & 0 & 24 & 3 & 1 & 2 & 3,63 & baik \\
\hline Kesadaran untuk mengikuti les & 29 & 2 & 12 & 1 & 14 & 1 & 3,00 & cukup \\
pelajaran matematika & 30 & 2 & 1 & 15 & 12 & 0 & 1,63 & kurang \\
\hline Rata-rata & & & & & & & $\mathbf{3 , 1 3}$ & cukup \\
\hline
\end{tabular}

Berdasarkan tabel 10 jawaban siswa dapat diketahui bahwa secara keseluruhan siswa memperlihatkan kriteria cukup terhadap pembelajaran matematika, dengan rerata 3,31 sehingga dapat disimpulkan bahwa siswa mempunyai kesadaran yang cukup dalam pembelajaran matematika.

Sikap seseorang terhadap sesuatu (misalkan terhadap matematika) sangat erat kaitannya dengan minat.Sebagian dari sikap bisa akibat dari minat. Agar siswa berminat atau tertarik terhadap matematika, paling tidak siswa harus melihat kegunaannya, keindahannya, atau karena matematika menantang. Selain itu mungkin juga siswa tertarik kepada matematika karena kesukaannya, argumentasinya jelas, soal-soalnya menantang, gurunya menyenangkan dan sebagainya (Darmin dalam Dahiana,2010: 30). Menurut Poerwadarminta (Dahiana, 2010: 30) mendefinisikan bahwa sikap adalah pandangan yang 
berdasarkan pendirian (pendapat atau keyakinan) sangat erat kaitannya dengan minat. Sedangkan minat menurut Ruseffendi (1991) mengemukakan bahwa minat seseorang terhadap matematika merupakan salah satu faktor untuk mengetahui sikap orang tersebut terhadap matematika. Artinya seseorang yang berminat terhadap matematika akan menumbuhkan sikap yang positif terhadap matematika. Untuk menumbuhkan minat dan sikap positif siswa terhadap matematika perlu diperhatikan antara lain kegunaan matematika bagi siswa dan cara guru menyampaikan matematika kepada siswa. Sehubungan dengan cara penyampaian materi, Hudojo (Dahiana,2013: 31) menjelaskan bahwa keberhasilan siswa belajar matematika dipengaruhi oleh penguasaan pengajar terhadap bahasan matematika kepada siswa. Lebih jauh Marina watie (Dahiana,2013:13) menegaskan bahwa di dalam kegiatan belajar mengajar guru hendaknya memusatkan perhatian pada usaha membangkitkan minat, semangat, daya cipta (kreativitas) dan kemampuan siswa untuk menemukan dan memecahkan masalah dengan upaya siswa sendiri.

Dilihat dari apa yang terjadi pada penelitian, ternyata minat dilihat dari aktivitas observasi siswa. Banyak faktor yang menyebabkan siswa memberi sikap positif terhadap diberikannya perlakuan dengan menggunakan pembelajaran kooperatif tipe STAD. Seperti terlihat dari skala minat yang peneliti berikan. Dari pernyataan yang peneliti berikan pada siswa, umumnya mereka setuju bahwa pembelajaran kooperatif tipe STAD memberi kemudahan kepada mereka dalam mempelajari matematika, membantu mereka dalam pemahaman matematika serta dapat mengurangi ketidaksenangan siswa terhadap matematika. Sedangkan angket yang diberikan kepada siswa yang mendapatkan pembelajaran ekspositori, hal ini dimungkinkan karena kondisi siswa benar-benar bersikap negatif, atau karena tidak begitu paham dengan maksud dari pernyataan-pernyataan yang ada pada angket, atau bisa jadi karena siswa beranggapan bahwa pengisian angket ini tidak perlu jawaban sesungguhnya. Indikator minat siswa menurut Slameto (2003) dan Djamarah, Syaiful bahri (2002). Banyak faktor yang menyebabkan siswa bersifat positif terhadap perlakuan dengan pembelajaran kooperatif tipe STAD, seperti terlihat pada hasil skala minat yang peneliti berikan pada siswa yang mendapatkan pembelajaran kooperatif tipe STAD. Dari pernyataan yang peneliti berikan pada siswa, umumnya mereka setuju bahwa pembelajaran kooperatif tipe STAD memberikan kemudahan kepada mereka dalam mempelajari matematika dan dapat mengurangi ketidaksenangan siswa pada matematika.

Dari penjelasan diatas dapat kita simpulkan bahwa minat siswa baik belum tentu memiliki kualitas peningkatan kemampuan pemahamannya baik pula, sebaliknya minat 
siswa yang kurang baik pun belum tentu memiliki kualitas peningkatan kemampuan pemahaman yang rendah pula. Ini semua terjadi karena minat bukan satu-satunya faktor yang ada mendorong pada kualitas peningkatan kemampuan pemahaman, ada banyak faktor lain yang mempengaruhi pembelajaran terkait.

\section{KESIMPULAN}

Berdasarkan hasil pengolahan dan analisis data mengenai kemampuan pemahaman matematika dan minat siswa peneliti bisa menyimpulkan hasilnya adalah minat pembelajaran Kooperatif tipe STAD lebih baik dan bersifat positif daripada Minat siswa dalam pembelajaran Ekspositori.

\section{DAFTAR PUSTAKA}

Anita Lie.2004. Cooperative Learning. Jakarta: Grasindo

Budiyono. 2003. penelitian pendidikan. Surakarta: Universitas Sebelas Maret

Hudojo, (2013). Pengembangan Kurikulum dan Pembelajaran Matematika. JICA. Universitas Negeri Malang

Indrawan, R \& Yaniawati, P (2014). Metodologi Penelitian. PT Refika Aditama

Prof.Dr.H.Wina Sanjaya, Penelitian Tindakan kelas. (Jakarta: Kencana.2009).hal 48

Ruseffendi, E.T. (2006), Pengantar kepada membantu Guru Mengembangkan Kompetensinya Dalam pengajaran matematika Untuk Meningkatkan CBSA. Bandung, Tarsito

Rusman (2012) Model-Model pembelajaran. Depok: PT Rajagrafindo

Slameto.(2003). Belajar dan Faktor-faktor yang Mempengaruhinya. Jakarta: Rineka Cipta

Slavin, R.E.(1995) Cooperative learning: teori,riset,and praktik $\left(2^{\text {th }}\right.$ ed). Sydney: AllymandBroon.

Uyanto,S.S.(2009) Pedoman Analisis data dengan SPSS. Yogyakarta:Graha Ilmu

Poerwandarminta. 2003. Kamus besar Bahasa Indonesia. Jakarta: Balai Pustaka.

Wahyuni, F(2012). Upaya meningkatkan Minat Belajar Matematika Siswa Kelas VII SMP Negeri 6 Yogyakarta Dengan Menggunakan Media Komik Melalui Model Pembelajaran Kooperatif Tipe Student Teams Achievement Divisions (STAD)" (Jurnal)

Wahyudin. (2009). Pembelajaran dan Model-model Pembelajaran. Jakarta : CV. Ipa Abong. 